\title{
Surface-Water Data and Statistics from U.S. Geological Survey Data-Collection Networks in New Jersey on the World Wide Web
}

\section{INTRODUCTION}

The U.S. Geological Survey (USGS), in cooperation with other Federal, State, and local agencies, operates and maintains a variety of surface-water data-collection networks throughout the State of New Jersey. The networks include streamflow-gaging stations, low-flow sites, crest-stage gages, tide gages, tidal creststage gages, and water-quality sampling sites. Both real-time and historical surface-water data for many of the sites in these networks are available at the USGS, New Jersey District, web site (http://nj.usgs.gov/), and water-quality data are available at the USGS National Water Information System (NWIS) web site (http://waterdata.usgs.gov/nwis/). These data are an important source of information for water managers, engineers, environmentalists, and private citizens.

Data from surface-water data-collection networks are used to:

- issue and administer permits for surface-water withdrawals and the discharge of treated wastewater;

- develop New Jersey instream water-quality standards;

- declare flood warnings along rivers and in back-bay areas of the State;

- design bridges, dams, and flood-control and other facilities;

- develop water-supply planning and droughtmanagement strategies;

- plan watershed-management activities;

- evaluate the suitability of streams for recreational activities such as fishing, swimming, and canoeing; and

- evaluate historical trends in streamflow and water quality and their relation to changes in the hydrologic characteristics of watersheds.

As part of a multi-year project to update statistics derived from streamflow data from surface-water data-collection networks in New Jersey through 2001, the USGS, in cooperation with the New Jersey Department of Environmental Protection (NJDEP), developed a site on the World Wide Web to provide rapid and easy access to this information. This fact sheet describes the types of information available at the web site.

Types of information currently available include streamflow, streamwater-quality, and tide-elevation data through 2001 and

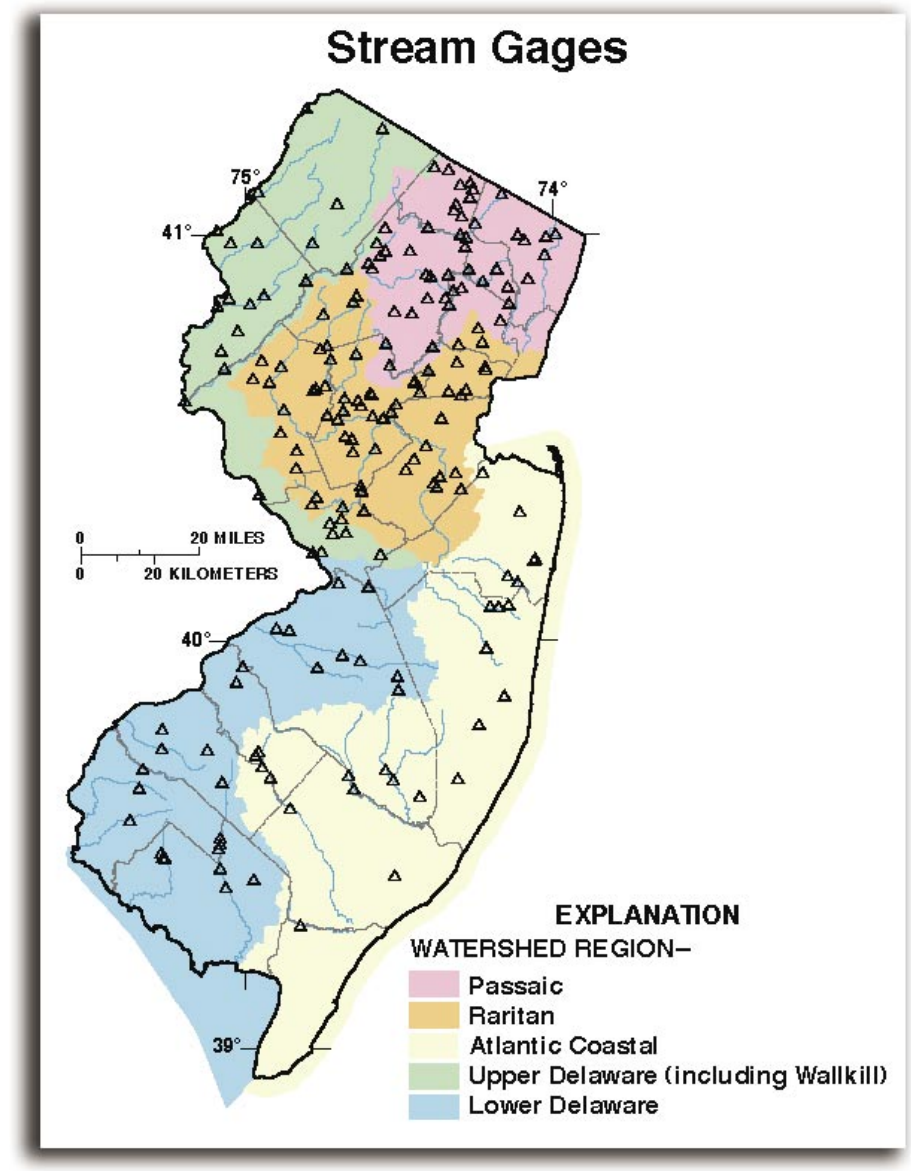

Figure 1. Screen capture from the U.S. Geological Survey surface-water data and statistics web site showing a map of New Jersey, the five water regions, and the locations of the streamflow-gaging stations.

statistics for streamflow data through 1990 for both active and inactive sites. Streamflow statistics are being updated through 2001. The web page includes location maps, associated site attributes, and basin characteristics for many of the sites. The web page can be found at http://nj.usgs.gov/flowstatistics/.

\section{DATA-COLLECTION NETWORKS}

The USGS data-collection networks for which data are included on the web page consist of six types: streamflow-gaging stations, low-flow sites, crest-stage gages, tide gages, tidal crest-stage gages, and water-quality sampling sites. To facilitate selection of sites, the State is divided into five water regions, developed by NJDEP for watershed-management purposes (fig. 1). 


\section{Continuous Streamflow}

Streamflow-gaging stations (fig. 2) provide a continuous record of streamflow at a predetermined time interval on a continual basis (Reed and others, 2001). The recording interval typically is 15 minutes but may be shorter or longer. The continuous-record streamflow-gaging-station network in New Jersey dates back to 1897 (Gillespie and Schopp, 1982). Daily mean flows currently are recorded at 92 streamflow gages and previously were recorded at an additional 104 gages (Reed and others, 2001). Streamflow statistics such as flow duration, high-flow frequency, and lowflow frequency are used to describe the volume of water flowing past a site and the frequency of occurrence of flows of a given magnitude. Flow durations are computed by first arranging daily mean streamflows in order of magnitude; from these streamflows, a cumulative frequency curve, which shows the percentage of

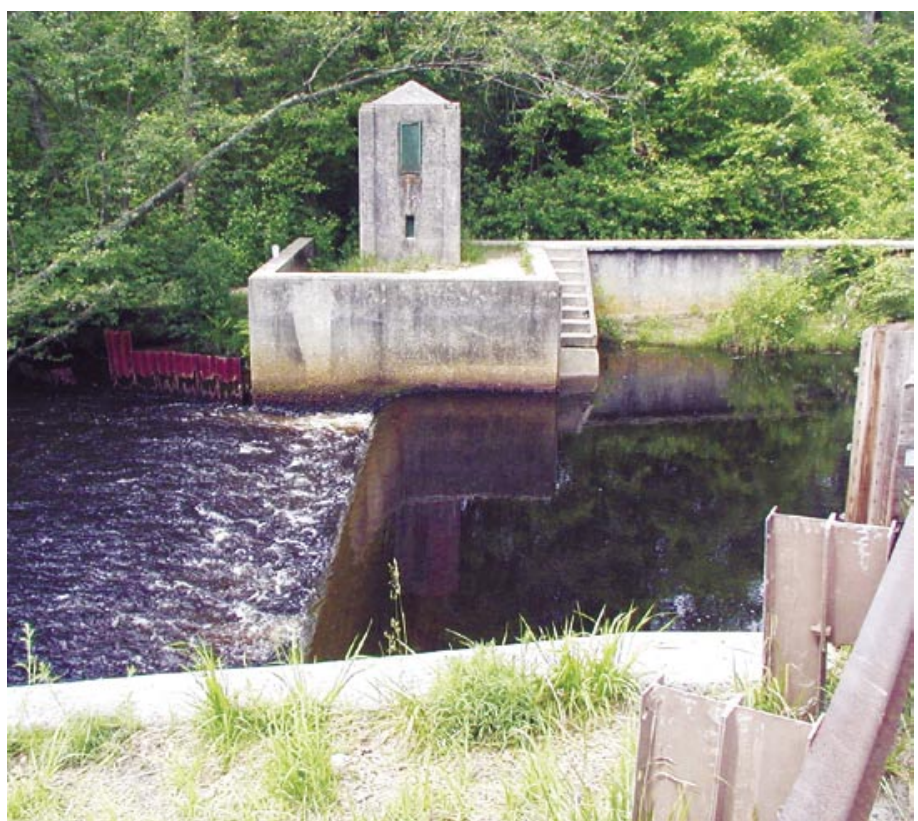

Figure 2. Streamflow-gaging station on the Batsto River at Batsto, New Jersey.

time that specified flows are equaled or exceeded (Riggs, 1972), is prepared. A log Pearson type III frequency distribution is used to compute frequency statistics that describe minimum and maximum mean daily flows for a given number of consecutive days (Riggs, 1968).

\section{Low Flow}

Instantaneous measurements of streamflow are made at lowflow sites at base-flow conditions. Base-flow conditions occur when streamflow consists primarily of ground-water discharge rather than direct runoff. A sufficient number of measurements is made to develop a relation between measured flows at low-flow sites and mean daily flows at nearby streamflow-gaging stations. This relation is used to estimate the frequency and duration of low streamflows at the low-flow sites. Low-flow statistics were calculated through use of the Maintenance of Variance Extension (MOVE1) method of correlation analysis (Hirsch, 1982).

In 1958 the USGS, in cooperation with the New Jersey Department of Conservation and Economic Development
(NJDEP's predecessor), Division of Water Policy and Supply, began a statewide program of base-flow monitoring at locations for which little or no streamflow data were available. Streamflow at base-flow conditions currently is measured at more than 50 sites; historically, base flow was measured at more than 300 additional sites (Reed and others, 2001).

\section{Crest Stage}

Crest-stage gages record peak river stages between visits by USGS personnel. Peak-flow data from crest-stage-gage sites dating back to 1954 are used to compute flood frequencies for each site through use of a log Pearson type III frequency distribution. Measurements of peak river stage currently are made at 110 sites: historically, peak river stage was measured at 80 additional sites (Reed and others, 2001).

\section{Tide Elevation}

Tide data are collected at two types of stations-(1) continuousrecord tide gages (fig. 3 ) and (2) tidal crest-stage gages. Tide elevations at most continuous-record tide gages are transmitted to base stations by telephone, radio, or satellite links (Summer, 1998). Tidal crest-stage gages are read manually and record the peak tide elevation since the last manual reading. The USGS has recorded limited tide-elevation data since 1921. Peak tide elevations currently are recorded at 30 continuous-record tide gages and 32 tidal crest-stage gages (Reed and others, 2001).

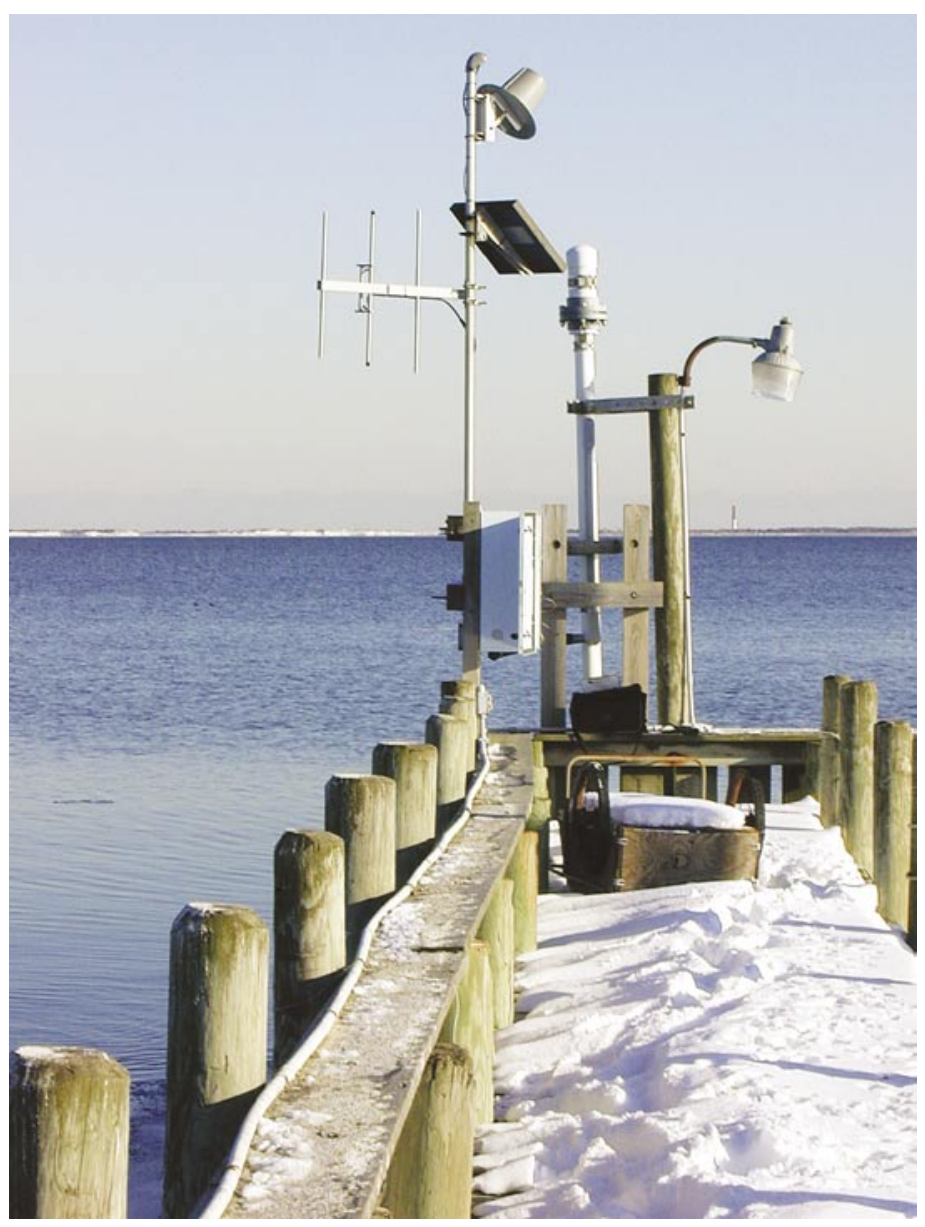

Figure 3. Continuous-record tide gage on the Barnegat Bay at Waretown, New Jersey. 


\section{Stream Gages}

\section{Watershed: Statewide}

\begin{tabular}{|c|c|c|c|c|c|}
\hline Site info & $\begin{array}{c}\text { Flow } \\
\text { statistics }\end{array}$ & Land use & $\begin{array}{c}\text { Station ID } \\
\text { (location map) }\end{array}$ & Station name & WMA \\
\hline I & $\mathrm{S}$ & L & $\underline{01368000}$ & WALLKILL RIVER NEAR UNION VILLE NY (Inactive) & 02 \\
\hline $\mathrm{I}$ & $\mathrm{S}$ & L & $\underline{01368720}$ & AUXILARY OUT OF UPPER GREEN WOOD LK AT MOE NJ (Inactive) & 02 \\
\hline I & $\mathrm{S}$ & $\mathrm{L}$ & $\underline{01377000}$ & HACKENSACK RIVER AT RIVERVALE NJ(Active) & 05 \\
\hline I & $\mathrm{S}$ & L & $\underline{01377500}$ & PASCACK BROOK AT WESTWOOD NJ(Active) & 05 \\
\hline I & $\mathrm{S}$ & L & $\underline{01378500}$ & HACKENSACK RIVER AT NEW MILFORD NJ(Active) & 05 \\
\hline I & $\mathrm{S}$ & L & $\underline{01378690}$ & PASS AIC RIVER NR BERNARDS VILLE NJ(Inactive) & 06 \\
\hline I & S & L & $\underline{01379000}$ & PASSAIC RIVER NEAR MILLINGTON NJ(Active) & 06 \\
\hline I & $\mathrm{S}$ & $\amalg$ & $\underline{01379500}$ & PASSAIC RIVER NEAR CHATHAM NJ(Active) & 06 \\
\hline I & $\mathrm{S}$ & $\mathrm{L}$ & $\underline{01379530}$ & CANOE BROOK NEAR SUMMIT NJ(Active) & 06 \\
\hline & $\mathrm{S}$ & $\mathrm{L}$ & $\underline{01379580}$ & PASSAIC RIVER NR HANOVRE wmmentive) & 06 \\
\hline
\end{tabular}

Figure 4. Screen capture from the U.S. Geological Survey surface-water-data and statistics web site showing information available for streamflow-gaging stations in New Jersey. (WMA is the New Jersey Department of Environmental Protection Watershed Management Area.)

\section{Water Quality}

Water-quality data are collected as part of USGS projects and cooperative studies with Federal, State, and local agencies in New Jersey (DeLuca and others, 2002). The USGS/NJDEP cooperative Ambient Stream Monitoring Network began operation in 1976. Surface-water samples collected at 112 sites from the cooperative monitoring network in 2001 were analyzed for waterphase concentrations of nutrients, common ions, biochemical oxygen demand, trace elements, volatile organic compounds, and pesticides (DeLuca and others, 2002). Data collected at sampling sites as part of USGS projects are also available on the web page. Continuous-record water-quality sampling (measurements made at least daily) began as early as 1949 at the Delaware River at Trenton station. Since then, daily records have been collected at more than 50 sites for one or more of the following constituents and properties: temperature, specific conductance, $\mathrm{pH}$, dissolvedoxygen concentration, turbidity, and sediment concentration. Currently, continuous-record water-quality data are available for the following stations: Ramapo River at Pompton Lakes, NJ (01388000); Passaic River below Pompton River at Two Bridges, NJ (01389005); and Delaware River at Trenton, NJ (01463500). Historic continuous-record water-quality data are not available on the web page.

Some surface-water data from the USGS data-collection networks are not available at this web site. These include streamflow data for miscellaneous sites, precipitation data, reservoir elevations, reservoir contents, and stream-diversion data, as well as historic streamflow measurements, stream stages, and tide elevations.

\section{MAPS}

Maps of USGS streamflow-data-collection networks in the State of New Jersey can be viewed at the web site. These maps can be used to view the locations of sites for which flow data and associated information are available. The site locations are plotted from the latitude and longitude data stored in the USGS Ground-Water Site Inventory (GWSI) database. The latitudes and longitudes of all USGS site locations were derived from USGS 7.5-minute topographic maps. The maps on the web page show the locations of active and inactive sites throughout the State in each of the six categories: streamflow-gaging stations, low-flow sites, crest-stage gages, tide gages, tidal crest-stage gages, and water-quality sampling sites (fig. 1). Two types of location maps are provided for each site: one shows the location of the site on a map of the northeastern United States and the other shows the location of the site on a map that includes streams, major roads, and towns in the vicinity of the site.

\section{PRESENTATION OF DATA}

The web site has links to tables containing site-location information, streamflow and water-quality data, flow statistics, and land-use information for each site. An example of the table of information available at the web site for each station type is shown in figure 4. The site-information table (Site info) can be accessed by clicking on the "l" on the same line as the station of interest. This table contains information about the site location and other facts about each site, including latitude, longitude, county, state, hydrologic-unit code, drainage area, station type, 
and type of data available, derived from the GWSI database. The table has links to available water-quality data and daily, monthly, and annual streamflow data located at the NWIS web site (http://waterdata.usgs.gov/nwis/). Information about site operation and an e-mail address for questions also are provided.

The flow-statistics table (Flow statistics) can be accessed by clicking on the "S" on the same line as the station of interest (fig. 4). This table contains statistics computed from low-flow, high-flow, and mean-daily flow data. The codes used in the table to identify statistics are explained in a definition table on the web page. Attributes listed in the flow-statistics table are flow-duration statistics (the percentage of time a particular flow is equaled or exceeded), "n"-day low flows and "n"-day high flows that occur at a particular recurrence interval, harmonic mean flow (the reciprocal of the reciprocal of the daily flows), mean annual flow, and monthly mean flow.

The land-use table (Land use) can be accessed by clicking on the "L" on the same line as the station of interest. This table contains 1995/97 land-use information for the drainage basin upstream from each site (fig. 4). The land uses are derived from a geographic information system (GIS) coverage developed from 1995/97 digital infrared aerial photos (N.J. Department of Environmental Protection, 2000) through use of the Anderson method of classification (Anderson and others, 1976). Land use is characterized on the basis of the percentages of urban, agricultural, forested, wetland, open water, and barren land in each basin. A 30-meter-grid digital elevation model (DEM) coverage of New Jersey and coordinates of the site location were used to create a basin boundary for each site. The 1995/97 landuse coverage was overlaid on the basin polygon. The size of the basin and the size of each land-use area within the basin were used to compute the land-use percentages listed in the table.

-Robert G. Reiser, Kara M. Watson, Ming Chang, and Steven P. Nieswand

\section{REFERENCES CITED}

Anderson, J.R., Hardy, E.E., Roach, J.T., and Witmer, R.E., 1976, $A$ land use and land cover classification system for use with remote sensor data: U.S. Geological Survey Professional Paper 964, $28 \mathrm{p}$.

Deluca, M.J., Hoppe, H.L., Doyle, H.A., and Gray, B.J., 2002, Water resources data for New Jersey--Water year 2001, Volume 3. Water-quality data: U.S. Geological Survey WaterData Report NJ-01-3, 580p.

Gillespie, B.D., and Schopp, R.D., 1982, Low-flow characteristics and flow duration of New Jersey streams: U.S. Geological Survey Open-File Report 81-1110, 164 p.

Hirsch, R.M., 1982, A comparison of four streamflow record extension techniques: Water Resources Research, v. 18, no. 4, p. 1081-1088.

New Jersey Department of Environmental Protection, 2000, Land use/land cover and impervious surfaces by watershed management area, 1995/97: Trenton, N.J., New Jersey Department of Environmental Protection, Bureau of Geographic Information and Analysis. (Accessed April 1, 2000, on the World Wide Web at URL http://www.state.nj.us/dep/gis/ lulc95shp.html).
Reed, T.J., Centinaro, G.L., Dudek, J.F., Corcino, V., and Steckroat, G.C., 2001, Water resources data for New Jersey-Water year 2000, Volume 1. Surface-water data: U.S. Geological Survey Water-Data Report NJ-00-1, 302 p.

Riggs, H.C., 1968, Frequency curves: U.S. Geological Survey Techniques of Water-Resources Investigations, book 4, chap. A2, $15 \mathrm{p}$.

Riggs, H.C., 1972, Low-flow investigations: U.S. Geological Survey Techniques of Water-Resources Investigations, book 4, chap. B1, 18 p.

Summer, W.M., 1998, New Jersey tide telemetry system: U.S. Geological Survey Fact Sheet 091-98, 2 p.
Contact for additional information:

U.S. Geological Survey Water Resources Division 810 Bear Tavern Road, Suite 206 West Trenton, NJ 08628 